\title{
Modele biznesowe w grach online i ich wpływ na bezpieczeństwo nieletnich
}

DOI: $10.47050 / 65591777.234-253$

Anne Mette Thorhauge

W niniejszym rozdziale opisano ewolucję modeli biznesowych w grach online w minionej dekadzie i wynikające z tego implikacje w zakresie ochrony nieletnich w środowiskach internetowych.

\section{Słowa kluczowe:}

gry online

modele biznesowe

hazard

młodzież 


\section{Business models in online gaming and their implications for the protection of minors}

DOI: 10.47050/65591777.234-253

Anne Mette Thorhauge

In this chapter I will describe how the business models in online gaming have evolved throughout the previous decade and discuss the implications this has for the protection of minors in online environments.

\section{Keywords:}

online games

business models

hazard

youth 


\section{Wprowadzenie}

Ochrona nieletnich w środowiskach online najczęściej skupia się na kwestiach dostępu do nieodpowiednich treści, dotyczących na przykład seksu i przemocy, czy możliwościach kontaktu z osobami o złych intencjach. Pierwsza z tych perspektyw stanowi swoistą spuściznę po wcześniejszych mediach, takich jak telewizja i film, a stosowane na ogół środki zaradcze opierają się na podejściach podobnych do wykorzystywanych uprzednio, jak klasyfikacja treści i kontrola rodzicielska. Drugi ze wspomnianych obszarów zagrożeń rozwinął się wraz z upowszechnieniem się usług internetowych jako jednego $z$ ważniejszych kanałów relacji towarzyskich, a wiążą się z tym próby tworzenia „bezpiecznych przestrzeni" dla dzieci lub kierowane do nich akcje edukacyjne, które mają na celu wyposażenie ich w wiedzę krytyczną umożliwiającą bezpieczne poruszanie się w sieci. Oprócz tego rodzaju tradycyjnych problemów pojawiają się kwestie rzekomego uzależniającego charakteru technologii mobilnych oraz gier i usług online. Obawa ta wynika z założenia, że stosowanie konkretnych rozwiązań może prowadzić do nadmiernego i niekontrolowanego zaangażowania w świat cyfrowy, co szkodliwie wpływa na dzieci.

W niniejszym opracowaniu zaproponowano i uzasadniono podejście alternatywne, koncentrujące się na ewolucji modeli biznesowych gier wideo oraz na tym, w jaki sposób są one wbudowane w strukturę aplikacji. Modele te często prowadzą do tego, że użytkownicy poświęcają coraz więcej czasu i pieniędzy na granie, nie powinno zatem dziwić, że gry są czasami porównywane z uzależniającymi substancjami albo praktykami. Niemniej przesunięcie punktu ciężkości z „patologii jednostki" na krytyczną analizę metod konstruowania tych gier pozwala $z$ innej perspektywy spojrzeć na zagadnienie ochrony młodych ludzi, $w$ tym na inne możliwe strategie pośrednictwa rodziców $\mathrm{i}$ - potencjalnie - ustawodawstwo. Stanowisko to zostanie uzasadnione w kolejnych podrozdziałach, w których omówiono sposób, w jaki hazard może występować w grach online, ponieważ stanowi to istotne tło dla rozwoju modeli biznesowych w tym obszarze. Następnie wyjaśniono, w jaki sposób ewolucja modeli biznesowych w grach online podąża za rozwojem usług internetowych i mikrotransakcji w sieci. Uzupełnieniem będzie opis, w jaki sposób tego rodzaju nowe podejście biznesowe jest implementowane $w$ grach na etapie ich projektowania - $w$ formie określonych „mechanizmów". W kolejnym podrozdziale podjęto kwe- 
stię dynamicznych zjawisk ekonomicznych w obrębie platform z grami i szerszego ekosystemu tych platform, co pociąga za sobą zjawiska gospodarcze i modele biznesowe, którymi warto się zainteresować w związku z ochroną nieletnich. W ostatniej części pojawi się odpowiedź na pytanie o to, dlaczego zmiany te powinny skłaniać do ponownego spojrzenia na pojęcie „ryzyka" w środowisku online, a także zostaną przedstawione strategie ochrony młodych osób w sieci.

\section{Gry i hazard w internecie}

Gry i hazard mogą być ze sobą powiązane na wiele sposobów, co ma bezpośrednie przełożenie na kwestię ochrony nieletnich. Do zagadnienia tego tradycyjnie podchodzi się z punktu widzenia psychologii, wykorzystując sposób diagnozy patologicznego hazardu (lub porównywalne listy potencjalnych objawów) w celu wyjaśnienia, dlaczego dana osoba zbyt dużo czasu poświęca na granie. Ostatnio jednak, w związku z rozwojem modeli biznesowych w grach online, pojawiły się inne możliwe podejścia. Dotyczą one częściowej konwergencji branż gier i hazardu w ramach mediów społecznościowych, która nastąpiła na początku drugiej dekady XXI w., co wpłynęło na zasady projektowania gier i wprowadzenie podejścia biznesowego w innych obszarach związanych z aplikacjami, a także przyczyniło się do powstania rzeczywistego hazardu na uboczu rynku kreowanego przez graczy. Nie można jednak stwierdzić, że gry i hazard są dwiema stronami tego samego medalu lub że wszystkie gry online należy rozpatrywać w kategoriach hazardu. Oznacza to raczej, że strategie pozyskiwania i utrzymania klientów oraz czerpania z nich dochodów (monetyzacja), stosowane w wielu różnych dziedzinach biznesu, pojawiają się w nowej formie w grach online, a niektóre z nich mają cechy wspólne z tradycyjnym hazardem. Ponadto trzeba zaznaczyć, że tradycyjne podejście do gier i hazardu, polegające na diagnozowaniu u nadmiernie aktywnych użytkowników "uzależnienia od gier wideo", nie wystarczy, by zrozumieć te cechy internetowych modeli biznesowych, które mogą budzić wątpliwości. W dalszej części szczegółowo wyjaśniono (na podstawie wyników badań) sposób, w jaki gry i hazard mogą być ze sobą powiązane. Dotyczy to:

$\rightarrow$ diagnozowania patologicznego hazardu u nadmiernie aktywnych graczy,

$\rightarrow$ symulacji klasycznych gier hazardowych, przede wszystkim w mediach społecznościowych, 
$\rightarrow$ strategii utrzymania i monetyzacji wbudowanych w mechanizmy gier,

$\rightarrow$ strategii utrzymania i monetyzacji wdrażanych w szerszym zakresie niż pojedyncza gra,

$\rightarrow$ tradycyjnego hazardu w wymiarze gospodarki tworzonej przez graczy (player-driven economies).

\section{Diagnozowanie patologicznego hazardu nadmiernie aktywnych graczy}

W obszarze psychologii można znaleźć wiele badań dotyczących pojęcia "uzależnienia od gier wideo". Choć opisują one różne objawy, ich podstawowe przesłanki są takie same. Za pomocą badań ankietowych na próbie graczy określa się zestaw objawów w celu zdefiniowania patologii, a na tej podstawie stwierdza się, czy można ich zaliczyć do grupy "uzależnionych". Choć taki model wyjaśnienia tego zjawiska był przedmiotem obszernych badań empirycznych, został jednak zakwestionowany wraz z upływem lat. Ponadto podejście to w szerszym ujęciu teoretycznym skłania się ku postrzeganiu nadmiernej aktywności w grach jako "słabości moralnej", a także ku traktowaniu wszystkich gier w taki sam sposób, mimo występowania między nimi wielu różnic. Takie podejście nie wystarczy do przeprowadzenia szczegółowej analizy tego, jak rozwijają się obecnie modele biznesowe w branży gier online.

\section{Symulacja klasycznych gier hazardowych, przede wszystkim w mediach społecznościowych}

Innym sposobem łączenia gier i hazardu jest częściowa zbieżność interesów firm działających w obu branżach, która pojawiła się na początku drugiej dekady XXI W., gdy podmioty dostrzegły możliwość dystrybucji gier za pośrednictwem środowiska mediów społecznościowych. Z jednej strony firmy zajmujące się hazardem uznały, że platformy mediów społecznościowych są nowym, lukratywnym rynkiem, z drugiej projektanci prostych gier online typu casual (gry codzienne, rekreacyjne), rozpowszechnianych na tych platformach, szukali inspiracji w tradycyjnych rozgrywkach hazardowych, aby stworzyć komercyjnie opłacalne aplikacje w środowisku, w którym użytkownicy byli wyraźnie niechętni do płacenia z góry. Zbieżność celów branż była tylko częściowa, ponieważ firmy oferujące gry wideo i gry hazardowe miały bardzo różne 
przekonania co do charakteru działalności gospodarczej. Doprowadziło to jednak do powstania wielu gier typu casual z elementami hazardowymi, począwszy od standardowego hazardu online w ramach różnych społecznościowych gier kasynowych przez symulacje kasyna po gry towarzyskie. Na ilustracji 1 zaprezentowano różne strategie hazardowe. Zebrane przykłady dowodzą jednocześnie, że nie wszystkie gry z elementami kasyna należy zaliczać do gier hazardowych.

Ilustracja 1. Gry i hazard w mediach społecznościowych (Gainsbury i in. 2014)

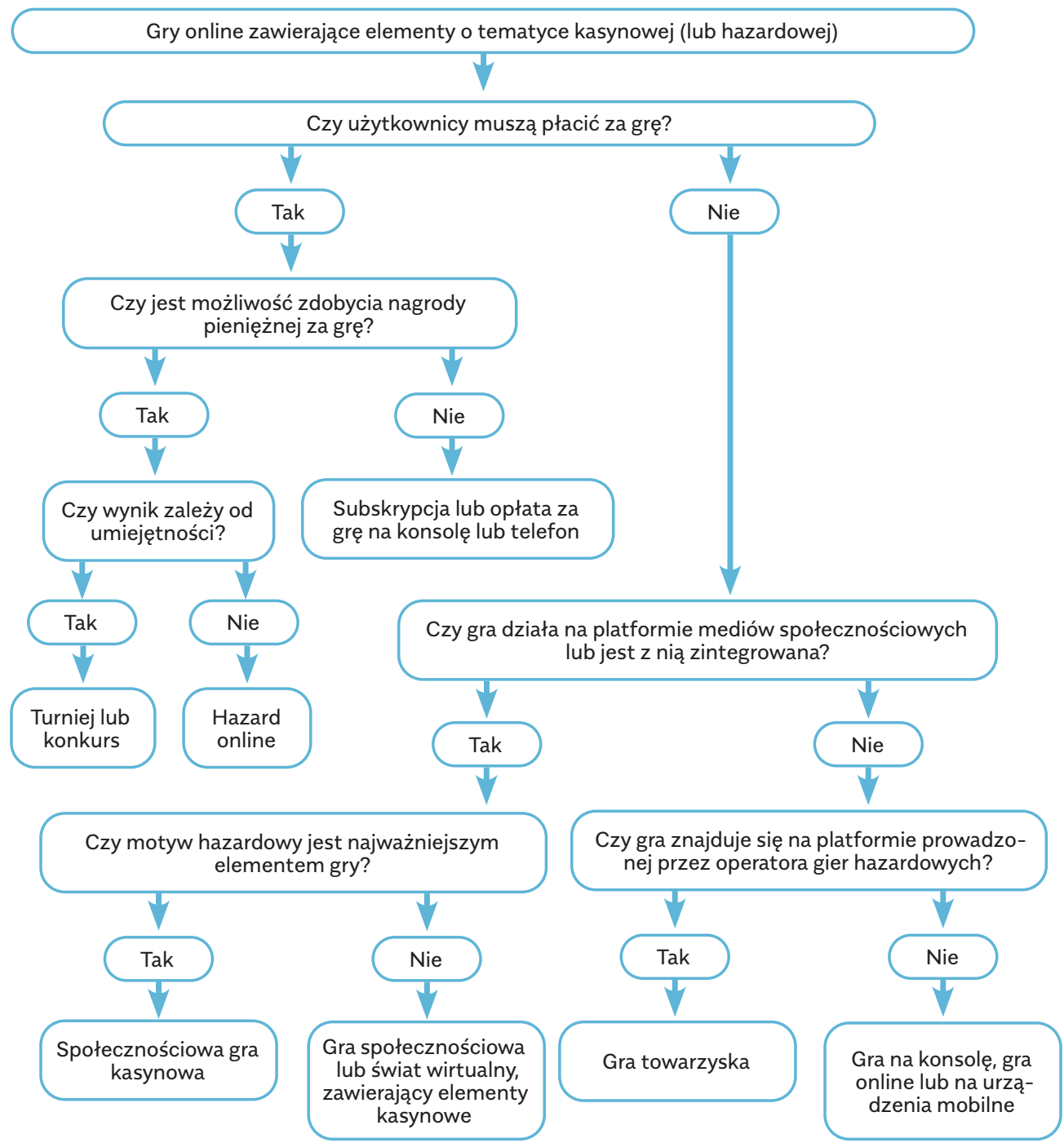


Strategie utrzymania i monetyzacji wbudowane w mechanizmy gier Konwergencja gier i hazardu występująca w aplikacjach dostępnych za pośrednictwem mediów społecznościowych stała się inspiracją dla projektantów gier online. O ile gry typu CS:GO, PUBG, Fortnite czy Rainbow Six z założenia opierają się na sprzedaży detalicznej lub subskrypcji, o tyle zasady darmowych gier z mediów społecznościowych są coraz częściej stosowane w produkcjach zaliczanych do głównego nurtu. Oznacza to silniejsze powiązanie modeli biznesowych z mikrotransakcjami, a co za tym idzie - skupienie się na strategii utrzymania i monetyzacji graczy (co jest uwzględniane w strukturze gier).

\section{Strategie utrzymania i monetyzacji wdrażane w szerszym zakresie niż pojedyncza gra}

Strategie utrzymania i monetyzacji graczy zostały nie tylko wbudowane w określone mechanizmy gier, ale stały się także elementem bardziej ogólnych analiz danych wykorzystywanych w projektowaniu aplikacji i opracowywaniu strategii biznesowych $w$ grach online. Wiąże się to z podziałem graczy zgodnie z wyrażaną przez nich chęcią do płacenia za grę oraz dostosowanie jej struktury do tej tendencji. Tego rodzaju analizy i dopasowywanie struktur gier do udokumentowanych wzorców ich użytkowania to obecnie elementy wszystkich profesjonalnych usług programowania, co samo w sobie nie stanowi problemu. W niektórych wypadkach może to być jednak część "drapieżnych strategii", na przykład celowej identyfikacji i manipulacji osób grających o wysokie stawki lub umyślnego tworzenia sytuacji bliskich wygranych w grach losowych. Oba sposoby znane są z tradycyjnych gier hazardowych, a dzięki zakrojonym na szeroką skalę gromadzeniu i wymianie danych użytkowników mogą być stosowane z jeszcze większą precyzją i skutecznością w środowisku online. Z oczywistych względów w większości krajów europejskich strategie te są uregulowane prawnie i warto byłoby się zastanowić, czy tego rodzaju ramy prawne mogłyby być stosowane w większym zakresie również w środowiskach internetowych (o czym będzie mowa w dalszej części rozdziału).

\section{Tradycyjny hazard w wymiarze gospodarki tworzonej przez graczy (player-driven economies)}

Wraz z rozwojem niezmiernie dynamicznych gospodarek tworzonych przez graczy w wirtualnym świecie pojawiły się również nie w pełni 
uczciwe praktyki biznesowe, między innymi oszustwa i zakłady. Zawieranie zakładów, w których obstawia się "skórki" do gier, czyli wirtualne przedmioty mające pewną wartość wymienną w szerszych społecznościach graczy, to obecnie zjawisko o ogromnej skali, które wiąże się z transakcjami rzędu miliardów dolarów. Chociaż w zakładach tego rodzaju nie wykorzystuje się konwencjonalnej waluty, to w praktyce obstawiane przedmioty, na przykład "skórki", są rodzajem pieniędzy w tym sensie, że wykazują wartość wymienną w danej społeczności. W związku z tym transakcje dotyczące "skórek" powinny być traktowane jako standardowy hazard, podlegający odpowiednim przepisom.

Tego rodzaju powiązania między grami a hazardem mogą być podstawą zrozumienia ewolucji modeli biznesowych w grach online, ponieważ modele oparte na mikrotransakcjach, które stają się obecnie coraz bardziej popularne w głównym nurcie przemysłu gier, wyłoniły się z aplikacji typu casual w mediach społecznościowych oraz z częściowej konwergencji między branżą rozrywki elektronicznej i hazardem. Zmiana ta wiąże się z przesunięciem akcentu w modelach biznesowych ze sprzedaży gier pudełkowych, utrzymywania stałych cen i pozyskiwania klientów na sprzedaży treści jako usług, mikrotransakcji oraz utrzymania i monetyzacji klientów.

\section{Rozwój modeli biznesowych w grach online}

Modele biznesowe w grach online uległy w ostatnich latach ogromnym zmianom, przechodząc od etapu „pudełkowego" przez różnego rodzaju subskrypcje do dzisiejszych złożonych modeli mikrotransakcyjnych. Rozwój ten nie dotyczy wyłącznie gier wideo, lecz stanowi ogólną tendencję wynikającą z tego, w jaki sposób technologie internetowe zakłóciły funkcjonowanie branż twórczych. „Produkty pudełkowe” są tutaj rozumiane jako gry (i inne wytwory kultury), które są przechowywane w formie papierowej, na płytach DVD lub w plikach cyfrowych i sprzedawane w tradycyjnych sklepach detalicznych. Jest to model biznesowy charakterystyczny dla tradycyjnych środków masowego przekazu, takich jak książki, filmy i albumy muzyczne, który w ostatnich latach został w znacznym stopniu zakwestionowany. Zmieniające się wzorce dystrybucji i konsumpcji w internecie utorowały drogę alternatywnym modelom biznesowym, które inaczej niż wcześniej wykorzystują treści. Jeden z nich - model oparty na subskrypcji - przekształca treści w usługę, do której można uzyskać dostęp przez internet po uiszcze- 
niu miesięcznej opłaty. Na tym modelu opierały się gry wideo, które w pierwszej dekadzie XXI w. najsilniej wyznaczały tendencje panujące na rynku, na przykład World of Warcraft. Użytkownicy płacili relatywnie niewielką sumę za pobranie aplikacji, a następnie uiszczali miesięczną opłatę za możliwość dalszego grania. O ile początkowa opłata była nieco niższa niż cena "gry pudełkowej", o tyle całkowita kwota szybko przekraczała kwotę płaconą za pojedynczą pozycję, ponieważ rozgrywka toczyła się przez dłuższy czas (kilka miesięcy lub lat). Obecnie model ten upowszechnia się $w$ tradycyjnych sektorach kultury (na przykład w branży filmowej czy muzycznej), w których firmy HBO, Netflix, Tidal lub Spotify wprowadzają "treści jako usługi” i miesięczne abonamenty jako alternatywę dla tradycyjnego modelu dystrybucji treści. Jednak nowsze zmiany w dziedzinie gier wideo (przede wszystkim ich rozwój w mediach społecznościowych) doprowadziły do powstania innego rodzaju strategii biznesowych, które często określa się zbiorczym mianem "modele mikrotransakcji" lub "graj za darmo". Oczywiście określenia "za darmo" nie należy tutaj traktować dosłownie, ponieważ w ramach tych modeli biznesowych z pewnością udaje się osiągać zyski (w przeciwnym razie nie byłyby to modele biznesowe). W większości "darmowych" gier można korzystać bez opłat w nieco okrojonej wersji, a przychody są generowane (poza reklamą) między innymi z dodatków w formie środków płatniczych, przedmiotów i usług, które można kupować w samej grze. W ten sposób producent może przyciągnąć szerokie grono użytkowników niezależnie od ich chęci do gry, zyskując jednocześnie pełną korzyść z tych osób, które są gotowe zapłacić nieco więcej niż inni. Również i w tym wypadku zmiany nie dotyczą wyłącznie dziedziny gier wideo, ale stały się powszechne na szerokim rynku, na przykład w sklepach App Store i Google Play, w których użytkownicy przyzwyczaili się do korzystania z aplikacji bez konieczności uiszczania jakichkolwiek opłat „z góry” (i przypuszczalnie nadal pozostają nieświadomi wielu innych metod czerpania zysków z ich aktywności).

Ewolucja modeli biznesowych w dziedzinie gier wideo i online odbywała się od produktów pudełkowych przez subskrypcję do różnych modeli mikrotransakcji odzwierciedlających bardziej ogólną tendencję w internecie. Juho Hamari i Aki Järvinen (2011) opisują, w jaki sposób zmiany te są w znacznie większym stopniu nastawione na utrzymanie i monetyzację graczy. Utrzymanie graczy polega na wydłużeniu czasu ich gry, a monetyzacja zmusza ich do płacenia w trakcie rozgrywki. 
Należy jednocześnie zauważyć, że utrzymanie i monetyzacja klienta to kluczowe czynniki w każdym modelu biznesowym, zarówno online, jak i offline. W supermarkecie, restauracji czy teatrze są stosowane strategie, których nadrzędnym celem jest przyciągnięcie do nich klientów, jak również strategie zatrzymania ich na dłużej, aby można było więcej im sprzedać. To samo dotyczy gier online i producentów aplikacji. Ponieważ kluczowa transakcja ekonomiczna w modelu pudełkowym jest zawierana z góry, gdy gracze kupują produkt, nacisk kładziony jest tutaj na pozyskiwanie klientów przez działania marketingowe. Dla porównania, kluczowym elementem modeli biznesowych opartych na subskrypcji jest doprowadzenie - za pomocą różnych rodzajów strategii utrzymania klientów - do sytuacji, że gracze będą płacić co miesiąc. Co więcej, ponieważ aplikacje typu „graj za darmo” wymagają zawierania żadnych początkowych ani miesięcznych transakcji, ich producenci wykorzystują alternatywne sposoby monetyzacji graczy, oferując im zakup różnych rzeczy lub sprzedawanie ich uwagi reklamodawcom. Tego typu elementy łączą gry online z wieloma innymi dziedzinami biznesu, stanowią jednak również wyjątek w związku z tym, że tego rodzaju założenia ekonomiczne są wbudowane w samą strukturę gier. Warto zatem przyjrzeć się tej kwestii.

\section{Sposób projektowania gry pod kątem utrzymania i monetyzacji graczy}

Jak wspomniano w poprzednim podrozdziale, każdy model biznesowy, niezależnie od okoliczności jego funkcjonowania, obejmuje strategie pozyskiwania, utrzymania i monetyzacji klientów. Interesującym aspektem gier online jest jednak sposób, w jaki tego rodzaju założenia biznesowe wbudowane są bezpośrednio w ich strukturę. Na przykład gra pudełkowa będzie skupiać się na przyciągnięciu klientów za pomocą atrakcyjnych zwiastunów i efektownych billboardów, podczas gdy aplikacja wykorzystująca mechanizm subskrypcji będzie w nieco większym stopniu koncentrować się na kwestiach, które sprawiają, że użytkownicy będą kontynuować rozgrywkę przez wiele dni lub miesięcy. Gry oparte na modelach mikrotransakcyjnych są zaś nieco bardziej nastawione na te aspekty, które motywują do nabywania przedmiotów, zasobów lub usług za rzeczywiste pieniądze. Juho Hamari i Aki Järvinen (2011) wskazują niektóre z omawianych tu mechanizmów gier, przy czym słowo „mechanizmy" oznacza modele ich struktury, które 
często powtarzają się w wielu grach i które kształtują wzorce interakcji podczas rozgrywki. Przykładem może być opracowanie i równoważenie siły zasobów w grach strategicznych, tworzenie i zrównoważenie ras oraz klas społecznych w grach fabularnych, jak również projektowanie broni i map w "strzelankach" online. O ile takie mechanizmy są tworzone przede wszystkim po to, aby rozgrywka miała sens i była atrakcyjna, o tyle, według przywoływanych autorów, coraz częściej stają się one również zagadnieniem biznesowym. Hamari i Järvinen wskazują mechanizmy gier online, które służą do pozyskiwania, utrzymania i monetyzacji graczy. Ich publikacja skupia się na grach typu casual w mediach społecznościowych, jednak wraz z przenikaniem mikrotransakcyjnych modeli biznesowych do bardziej konwencjonalnych gier online są one z całą pewnością istotne również i w tej dziedzinie.

\section{Mechanizmy gier tworzone w celu pozyskiwania klientów}

Jako przykłady mechanizmów gier, które służą pozyskiwaniu klientów (cel biznesowy), Juho Hamari i Aki Järvinen (2011) podają między innymi podarunki, znajomych - sąsiadów i znajomych - pomocników. Podarunki to przedmioty zdobywane przez użytkownika w trakcie gry, który można przekazać znajomemu, zapraszając go w ten sposób do przyłączenia się do rozgrywki. Gracz może także zyskać przewagę, współpracując ze znajomymi jako sąsiadami lub zatrudniając ich jako pomocników i zapraszając ich do gry. Mechanizm taki jest szczególnie rozpowszechniony w grach typu casual osadzonych w sieciach społecznościowych (na przykład na Facebooku), ponieważ umożliwia on dostawcy gry wykorzystanie powiązań społecznościowych poszczególnych graczy do uzyskania przewagi dzięki efektowi sieciowemu oraz przez obsadzenie użytkowników aplikacji w roli dobrowolnych pracowników marketingu, którym nie trzeba płacić wynagrodzenia.

\section{Mechanizmy gier tworzone w celu utrzymania klientów}

Mechanizmy gier służące utrzymaniu klientów to między innymi uzupełnianie profilu, tutoriale (samouczki), nagrody za nieprzerwaną grę, kary za wylogowanie, codzienne bonusy czy zachęcanie innych do tworzenia sieci (Hamari, Järvinen 2011).

Uzupełnianie profili i tutoriale są typowymi „technikami wprowadzającymi", które służą angażowaniu użytkowników w początkowej fazie rozgrywki. Podczas uzupełniania profilu gra sygnalizuje za pomocą 
pasków postępu i podobnych funkcji interfejsu, jak wiele czasu pozostało do zakończenia tego procesu, z kolei tutoriale ułatwiają "miękkie” wejście do gry i łatwe uczenie się w jej trakcie.

Bonusy za nieprzerwany udział w grze lub codzienną rozgrywkę oraz kary za wylogowanie to kwestie związane ze strukturą systemów nagradzania w rozgrywce i ich wpływem na utrzymanie użytkownika. Rozwiązania te uwzględniają tworzenie różnego rodzajów nagród, rozplanowanie procesu nagradzania na cały cykl gry oraz jego łączenie z konkretnymi rodzajami rozgrywek. Zachęcanie do uczestnictwa w sieci wpływa ponadto na tworzenie i utrzymywanie grup oraz społeczności użytkowników danej aplikacji, co jest kolejnym ważnym powodem, dla którego wracają oni do określonych gier (spędzanie czasu ze znajomymi). Środowiska akademickie poświęcają wiele uwagi strukturom systemów bonusów, w tym konkretnym strategiom „rozplanowania nagród", ponieważ właśnie w tym obszarze można dostrzec cechy wspólne nowych modeli biznesowych gier online z hazardem.

\section{Mechanizmy gier tworzone w celu monetyzacji klientów}

Juho Hamari i Aki Järvinen (2011) opisują również zbiór mechanizmów związanych z monetyzacją graczy, między innymi podwójne środki płatnicze, podawanie cen w kilku walutach, potrzeby wbudowane w strukturę gry, sztuczne utrudnienia, psucie się, deficyt, wirtualne środki płatnicze, przedmioty kolekcjonerskie i możliwość prezentowania się. Podwójne środki płatnicze i ceny w kilku walutach prowadzą do rozmywania rzeczywistej wartości przedmiotów, aby zachęcić graczy do wydawania większej ilości pieniędzy niż zazwyczaj. Potrzeby wbudowane w grę i sztuczne utrudnienia dotyczą tworzenia sytuacji w świecie gry, w których użytkownik napotyka dodatkowe przeszkody lub jest zmuszony do bardzo powolnej rozgrywki, o ile nie wyda dodatkowych pieniędzy. Psucie się, deficyt i wirtualne środki płatnicze dotyczą tworzenia tych środków i innych zasobów w grze (granica między nimi jest nieostra) zgodnie z zasadami deficytu i psucia się w celu zapewnienia popytu. Przedmioty kolekcjonerskie to te, które gracze mogą zdobywać i którymi mogą się chwalić. Przykładem może być zakup, zbieranie i wymiana "skórek" w grach takich jak PUBG, CS:GO, Fortnite i Rainbow Six. "Skórki" to tak zwana kosmetyka, obejmująca między innymi przebrania czy ozdoby na broń, które nie dają żadnej przewagi w rozgrywce, ale mogą uzyskać wysoką wartość jako przedmioty kolekcjonerskie 
i zapewniają uznanie w społeczności graczy. Dla niektórych grup kupowanie i wymiana "skórek" stały się najważniejszymi aspektami gry, co wpłynęło na powstanie szczególnego rodzaju rynku, tworzonego przez graczy ponad poziomem gier.

Juho Hamari i Aki Järvinen napisali artykuł w 2011 r., ale od tego czasu pojawiła się kolejna istotna technika monetyzacji graczy - loot box. Są to „pojemniki” (pudełka, skrzynki), które użytkownicy zbierają albo zdobywają w trakcie gry. Aby uzyskać dostęp do zawartości takiej skrzynki, gracz musi zapłacić za klucz lub innego rodzaju przedmiot. Dopiero po dokonaniu zakupu gracz poznaje zawartość pojemnika i ma okazję się przekonać, czy był on wart swojej ceny. Tego rodzaju wprowadzenie czystego przypadku do transakcji gospodarczych związanych z grą (wraz ze wspomnianym wcześniej rozplanowaniem nagród) doprowadziło do powstania pewnych kwestii problemowych dotyczących modeli biznesowych w grach online, upodabniających się w coraz większym zakresie do działań hazardowych. Aby jednak w pełni podjąć ten temat, należy wyjść poza mechanizmy projektowania poszczególnych gier i przyjrzeć się określonej dynamice gospodarczej, która rozwija się w szerszym wymiarze społeczności graczy i platform dystrybucji gier.

\section{Gospodarka tworzona przez graczy i pochodne praktyki rynkowe}

W poprzednim podrozdziale przedstawiono kilka przykładów na to, w jaki sposób można tworzyć mechanizmy gier w celu pozyskania, utrzymania i monetyzacji graczy. Lista ta nie jest oczywiście kompletna, stale się bowiem rozwija, czego przykładem mogą być loot boxy. Aby jednak w pełni zrozumieć modele biznesowe w grach online, należy przyjrzeć się ich powiązaniom z gospodarką tworzoną przez graczy, która rozwija się w szerszym wymiarze środowiska gier. Niektóre grupy graczy, o czym wspomniano wcześniej, mogą przekształcić kolekcjonowanie i wymianę "skórek" w odrębną grę, tworząc w ten sposób kolejny rodzaj zjawisk rynkowych, takich jak wymiana handlowa, oszustwa i zakłady między graczami. Specjalne strategie projektowania gier umożliwiły i propagują takie zjawiska, ale fenomen ten wynika także z zaangażowania graczy jako podmiotów gospodarczych i „przedsiębiorców" oraz z punktu styku gier z innymi platformami ekonomicznymi i rynkami.

Wspieranie przez producentów rynku tworzonego przez graczy wiąże się z pojawieniem się zasobów, które mogą być wykorzystywane jako 
środki płatnicze. Klasycznym przykładem jest funkcjonowanie „złota” w World of Warcraft jako waluty wymienialnej, zarówno w grze, jak i poza nią. Zdobywa się je przez wykonywanie zadań, pokonywanie potworów lub zbieranie różnych przedmiotów, które mogą być sprzedawane w domach aukcyjnych w ramach aplikacji. W ten sposób „złoto" pełni funkcję środka płatniczego w grze. Ponieważ jednak zbieranie tego zasobu zajmuje sporo czasu, niektórzy gracze kupują go za prawdziwe pieniądze. Popyt na "złoto" w World of Warcraft wywołał zjawisko „chińskich farmerów”, czyli graczy, którzy zbierają je w grze i sprzedają za dolary $w$ ramach pracy zarobkowej. Przedmiotami podobnej wymiany w grze i poza nią mogą stać się nie tylko środki płatnicze. Inne zasoby, ze względu na ich atrakcyjność, deficyt lub stabilną wartość, mogą zyskać status środka płatniczego w szerszej grupie i społeczności graczy (na przykład "skórki” i klucze do loot boxów). Względna łatwość realizacji i „zgodność z prawem” tej praktyki zależy oczywiście od tego, jakie konkretne rozwiązania wybierze dostawca gry, na przykład czy umożliwi lub zakaże wymian handlowych między użytkownikami aplikacji, co ma podstawowe znaczenie dla dynamiki gospodarki kreowanej przez graczy. Mogą oni wprawdzie nadal handlować przedmiotami w grach, które nie udostępniają tej możliwości, ale jest to proces żmudny i bardziej ryzykowny do przeprowadzenia. Ponadto dostawcy gier i właściciele platform mogą mniej lub bardziej utrudniać wymianę środków płatniczych występujących w grach na realną walutę, na przykład dolary lub euro. Przykładem jest stojąca za World of Warcraft firma Blizzard, która przez długi czas starała się przeciwdziałać procederowi „chińskich farmerów złota", ponieważ uznała go za sprzeczny z zasadami gry. Z kolei firma Valve, która stworzyła Steam, w znacznie szerszym zakresie umożliwia handel w ramach tej platformy i poza nią, udostępniając swój interfejs programistyczny do celów obrotu "skórkami" przez osoby trzecie.

Sposób zaprojektowania wirtualnych przedmiotów i środków płatniczych, jak również względna łatwość prowadzenia transakcji handlowych przez graczy, to czynniki umożliwiające powstanie rynków kreowanych przez graczy, które można opisać w kategoriach zaczerpniętych z tradycyjnej ekonomii, takich jak podaż i popyt, deficyt oraz inflacja. Ponieważ społeczności użytkowników wspólnie nadają konkretnym przedmiotom występującym w grze określoną wartość, stają się one elementem wymiany gospodarczej i mogą być przekształcone w pełnowartościową walutę. Na przykład wspomniane klucze do loot boxów stały się 
ważną walutą stosowaną w wymianie "skórek", najprawdopodobniej ze względu na ich względnie stabilną wartość. Deficyt danego przedmiotu (zaprojektowany), a także wahania popytu mogą spowodować wzrost i spadek cen. Nie jest to zjawisko nowe: znaczki, stare monety czy karty do gry Magic the Gathering to przykłady przedmiotów kolekcjonerskich, których wartość znacznie przewyższa ich wartość materialną, w związku z tym, że są to obiekty pożądane w określonych społecznościach. Niemniej jednak dynamiczny, połączony i globalny charakter gier online oznacza, że stanowią one relatywnie szersze zjawisko gospodarcze. Ponadto w dużej mierze nieuregulowany charakter tego rodzaju rynków doprowadził do pojawienia się kontrowersyjnych praktyk gospodarczych.

Ogromna skala wymiany sprawia, że niektórzy gracze uciekają się do nieetycznych działań w celu zdobycia własności innych użytkowników, na przykład oszustw i kradzieży. Może się to zdarzać między przyjaciółmi w świecie rzeczywistym lub między obcymi sobie osobami na rynkach internetowych. Gracz może na przykład skorzystać z tego, że znajomy znajduje się z dala od klawiatury, aby wejść na jego profil i przenieść pożądany przedmiot na własne konto. $Z$ kolei na rynkach internetowych gracze mogą oszukiwać, odmawiając oddania kupującemu przedmiotu po przekazaniu przez niego pieniędzy.

Ponadto sieciowy charakter rynku gier online sprawia, że stykają się one z innymi, bardziej podejrzanymi rodzajami zjawisk gospodarczych w internecie, takimi jak gry hazardowe i zakłady. Wspomniane wcześniej obstawianie "skórek" oznacza uprawianie hazardu, podobnego do tego, z jakim można się spotkać w symulacjach klasycznych gier kasynowych, takich jak ruletka czy blackjack. Zjawisko to jest obecne w gospodarce tworzonej przez graczy, ponieważ w ramach gry nadaje się przedmiotom - takim jak „skórki" czy klucze - powszechnie uznawaną wartość materialną. Obecne systemy prawne mają trudności z uznaniem tego zjawiska za hazard ze względu na stosunkowo nowy i dynamiczny charakter gier online: różne przedmioty mogą zyskiwać lub tracić wartość pieniężną zgodnie ze wzrostem lub spadkiem popularności różnych gier, co oznacza, że nowe "waluty" mogą pojawiać się i znikać takim tempie, że systemy prawne nie będą $w$ stanie sobie $z$ nimi poradzić.

Tego rodzaju wymiany i praktyki gospodarcze występują w warunkach szerszego systemu platform i z tego powodu znajdują się na styku wielu dziedzin działalności gospodarczej. Jednym z ważniejszych przy- 
kładów jest tutaj YouTube, którego związek z grami online jest oczywisty, gdyż filmiki ich dotyczące to jeden z najważniejszych gatunków tej platformy. Niektóre z wyznaczających tendencje gwiazd YouTube'a, między innymi PewDiePie, JackSepticEye, Johnontheradio czy Cryoz, przedstawiają gry jako podstawowe treści swoich filmików. Ich zarobki opierają się przede wszystkim na liczbie odsłon (model biznesowy oparty na zasadach YouTube'a). Oprócz tego nawiązują oni współpracę z osobami aktywnymi w dziedzinie gier online. Są "sponsorowani” - otrzymują "skórki" lub ich zestawy, co zwiększa popyt na te konkretnie produkty na rynku tworzonym przez graczy. Oprócz tego youtuberzy prowadzą konkursy, w których rozdają darmowe upominki w formie "skórek" i przedmiotów występujących w konkretnych grach, reklamując w ten sposób dane tytuły i związane z nimi rynki. O ile przykłady te mieszczą się bez wątpienia w kategoriach tradycyjnego marketingu, niektórzy youtuberzy idą krok dalej, współpracując również z nie do końca uczciwymi podmiotami, organizującymi na przykład zakłady, w których obstawia się „skórki". Reklamują między innymi kody promocyjne do stron, na których można obstawiać "skórki", i otrzymują niewielkie wynagrodzenie za każdym razem, gdy użytkownik wejdzie na tego rodzaju witrynę, co oznacza, że bezpośrednio kierują oni w te miejsca swoich (głównie młodych) odbiorców. W rezultacie, aby w pełni rozumieć właściwości i oddziaływanie modeli biznesowych w grach online, należy wziąć pod uwagę ich punkty styku z "działalnością biznesową gwiazd" YouTube'a.

Reasumując, gry online mogą z jednej strony być postrzegane jako przedmioty kultury mające na celu utrzymanie i monetyzację użytkowników, a z drugiej jako platformy dla szerszych rynków tworzonych przez graczy, z których wynikają różnego rodzaju praktyki gospodarcze, w tym oszustwa i zakłady. Ponadto, ze względu na ich sieciowy charakter, przecinają się one $z$ innymi dziedzinami biznesu $w$ internecie, takimi jak platformy strumieniowe. $W$ rezultacie modele biznesowe oraz sposób ich wbudowania w strukturę gier i szerszy ekosystem platform staje się kluczowym zagadnieniem dotyczącym ochrony nieletnich w internecie.

\section{Implikacje w zakresie ochrony nieletnich w dobie internetu}

Zagadnienie modeli biznesowych w grach online jest na tyle złożone, że wymaga szerokiej i wielostronnej analizy z punktu widzenia 
ochrony nieletnich w internecie. Przede wszystkim zmusza nas ono do spojrzenia poza tradycyjne problemy, takie jak nieodpowiednie treści lub „uzależnienie", i zwrócenia się ku temu, że zabawa dzieci i młodzieży oraz interakcje społeczne odbywają się w skomercjalizowanym środowisku. Trzeba dodać, że środki zaradcze dotyczące bardziej problematycznych aspektów tego zjawiska powinny obejmować edukację dzieci i młodzieży oraz skuteczniejsze egzekwowanie przepisów dotyczących strategii biznesowych, które wprowadzają użytkowników w błąd i służą manipulacjom.

\section{Na co powinniśmy zwrócić uwage - budzące wątpliwości modele biznesowe w grach online}

Jak wcześniej wspomniano, uzależnienie od gier wideo staje się coraz większym problemem w związku z korzystaniem przez dzieci i młodzież z mediów cyfrowych. Obawy te opierają się na założeniu, że użytkowanie określonych technologii cyfrowych może prowadzić do nadmiernej i niekontrolowanej aktywności, podobnej do patologicznego hazardu lub nadużywania alkoholu i narkotyków. Niemniej jednak, jak wynika z możliwych powiązań między grami a hazardem, tego rodzaju patologizacja dzieci i młodzieży prowadzi do uznawania nadmiernej aktywności za „moralną słabość", niezależnie od tego, czy dotyczy to dzieci, czy rodziców, a także do traktowania wszystkich gier na równi. Konstruktywnym podejściem byłoby zatem poddanie omawianych tu gier i mediów bardziej krytycznej analizie pod kątem stosowanych w nich strategii biznesowych oraz strategii utrzymania i monetyzacji graczy. Wiąże się to, po pierwsze, z bardziej krytyczną oceną modeli biznesowych typu "graj za darmo" stosowanych w aplikacjach online i poza nimi, a po drugie - z poświęceniem większej uwagi szarej strefie między grami online a standardowym hazardem na obrzeżach działalności biznesowej gier online.

Krytyczna ocena modelu "graj za darmo" oznacza uznanie, że tego rodzaju gry (i aplikacje) nie są bezpłatne. Niezależnie od tego, czy płacimy za nie poświęconym czasem i uwagą, przekazanymi danymi czy dokonując mikropłatności na jednym z etapów gry, jakieś koszty ponosimy. Biorąc to pod uwagę, trzeba stwierdzić, że określnie "darmowy" może wprowadzać konsumentów w błąd. Jest to problem o tyle, że wielu rodziców i opiekunów pozwala swoim dzieciom na korzystanie z różnych aplikacji na ich urządzeniach, o ile nie zawierają one przemocy 
i nie trzeba za nie płacić. Jednak właśnie w tego rodzaju grach stosowane mogą być bardzo agresywne strategie utrzymania i monetyzacji klientów, zatem jeśli naszym celem ma być ochrona praw i dobra dzieci oraz młodzieży, powinniśmy raczej szukać gier o ustalonych cenach i przejrzystych modelach biznesowych. Nie trzeba dodawać, że nie dotyczy to tylko gier bezpłatnych. Wraz z przyzwyczajaniem się użytkowników do darmowego korzystania z wszelkiego rodzaju aplikacji, takie zasady biznesowe przeniknęły do platform dystrybucyjnych takich jak App Store i Google Play. Przykładem może być tu aplikacja jednej z sieci restauracji, dzięki której użytkownicy mogą "wygrywać" darmowe posiłki, naciskając raz dziennie odpowiedni przycisk. Rozprzestrzenianie się tych modeli biznesowych w szerszym obszarze rynków internetowych sprawia, że jeszcze bardziej nagląca stała się potrzeba opracowania środków zaradczych.

Poza wbudowywaniem strategii utrzymania i monetyzacji klientów w mechanizmy darmowych gier i aplikacji rynki kreowane przez graczy pociągają za sobą wiele pochodnych praktyk gospodarczych (na przykład oszustwa i hazard), na które powinniśmy zwrócić uwagę. Należy podkreślić, że nie oznacza to utożsamienia grania z hazardem, gdyż nadal są to stosunkowo odmienne zjawiska, a korzystanie z aplikacji to nie to samo, co bycie patologicznym hazardzistą. Niemniej jednak, gdy dzieci i młodzież korzystają z internetu, aby brać udział w opartych na rywalizacji grach zespołowych, coraz częściej odbywa się to w otoczeniu tego rodzaju praktyk gospodarczych. Dlatego jest ważne, aby dzieci, młodzież i opiekunowie dysponowali wiedzą potrzebną do krytycznej refleksji nad tymi zagadnieniami oraz do unikania podejrzanych okoliczności i transakcji. Jednocześnie należy sprawić, aby wprowadzające w błąd i oparte na manipulacji strategie biznesowe regulowane były w ten sam sposób w internecie co w świecie rzeczywistym.

\section{Edukacja medialna i regulacje medialne - jak sobie z tym radzić?}

Odpowiednie podejście twórców modeli biznesowych w grach online powinno obejmować kilka obszarów. Z jednej strony trzeba zaktualizować umiejętności dzieci, młodzieży i opiekunów w zakresie krytycznego korzystania z mediów, opartego na wiedzy dotyczącej sposobu funkcjonowania modeli biznesowych w środowiskach online. $Z$ drugiej strony konieczne jest zidentyfikowanie i zweryfikowanie ram prawnych dotyczących wprowadzających w błąd i opartych na manipulacji 
strategii biznesowych w świecie rzeczywistym, a także zastanowić się, w jaki sposób można je zastosować do internetu.

Jednym z oczywistych sposobów postępowania w pierwszym obszarze jest przekazanie dzieciom, młodzieży i opiekunom odpowiedniej wiedzy, dzięki której będą mogli bezpiecznie poruszać się w tym środowisku. Wiąże się to z poszerzeniem obecnej edukacji w zakresie posługiwania się technologiami cyfrowymi o krytyczną analizę modeli biznesowych w środowiskach internetowych. W związku z przenikaniem mediów cyfrowych do każdego aspektu codziennego życia w ostatnich kilkunastu latach umiejętnościom korzystania z mediów i technologii cyfrowych poświęca się coraz więcej uwagi. W następstwie tych zmian wielu naukowców zaczęło podkreślać znaczenie wyjścia poza perspektywę opartą jedynie na umiejętnościach lub kompetencjach dotyczących korzystania z mediów w stronę krytycznego podejścia do tych umiejętności jako zdolności rozumienia i refleksji nad społecznymi i ideologicznymi interesami osadzonymi w mediach (cyfrowych) pod każdą ich postacią. Jak wcześniej wspomniano, powinno to również obejmować krytyczną znajomość modeli biznesowych i zasad leżących u ich podstaw, a także tego, w jaki sposób są one wbudowane w struktury aplikacji i platform.

Rozwiązanie kwestii wątpliwych modeli biznesowych w warunkach online nie powinno leżeć wyłącznie w gestii jednostek, a za uregulowanie zdecydowanie "drapieżnych strategii" w tym środowisku odpowiedzialność powinny ponosić władze. Jak stwierdzono kilkakrotnie w poprzednich podrozdziałach, przecinanie się gier i hazardu online prowadzi z czasem do stosowania strategii opartych na manipulacji. Mogą nimi być na przykład wprowadzające w błąd systemy rozplanowania nagród oraz identyfikowanie osób szczególnie podatnych na tego rodzaju działania. Istnieją uzasadnione powody, dla których w wielu krajach europejskich strategie tego rodzaju podlegają określonym przepisom i nie ma żadnych argumentów przemawiających za tym, aby takie ramy prawne nie miały zastosowania $w$ internecie. Jednym z oczywistych obszarów, od którego należy zacząć działanie, są oferty lub reklamy dotyczące standardowego hazardu kierowane do osób nieletnich, co jest nielegalne w większości krajów w Europie. Jest to niezgodne z prawem zarówno w internecie, jak i poza nim, i dotyczy między innymi reklamowania w serwisie YouTube kodów promocyjnych do stron prowadzących zakłady, w których obstawia się "skórki", 
a także przekazywania danych z profili osób nieletnich na platformach oferujących gry stronom trzecim, organizującym tego rodzaju działania hazardowe. Warto się również zastanowić, w jaki sposób można zastosować w internecie obowiązujące w niektórych krajach europejskich przepisy dotyczące wprowadzającego $w$ błąd rozplanowania nagród i celowego ukierunkowania tych działań na osoby szczególnie podatne. Stoimy zatem przed wieloma wyzwaniami, ale równie wiele jest możliwych środków zaradczych, które możemy zastosować. 